\title{
Do silenciamento à autonomia: representações e rasuras das subalternidades femininas em A Terceira Mãe, de Julieta Monginho
}

From silencing to autonomy: representations and erasures of female subalternities in A Terceira Mãe, by Julieta Monginho

Jorge Vicente Valentim

Universidade Federal de São Carlos

Ailton Pirouzi Júnior

PPGLit/Universidade Federal de São Carlos

\section{DoI}

https://doi.org/10.37508/rcl.2021.n45a427

\section{RESUMO}

O trabalho propõe uma leitura do romance A terceira mãe (2008), da escritora portuguesa Julieta Monginho, a partir da percepção de um movimento que vai do silenciamento à autonomia feminina. Na sequência de trajetórias de mãe, filha e neta, a autora entrelaça três gerações distintas de mulheres em contextos diferentes ao longo dos séculos XX-XXI. Ligadas pelo sangue e pelas experiências, as três personagens formam o foco da trama narrativa, com uma especial centralidade sobre a figura da primeira mãe, Rosalina. Assim, do silenciamento imposto à mãe/avó, por fatores sócio-políticos, à autonomia da neta, Joana, a efabulação romanesca tece as trajetórias dessas três mulheres portuguesas.

Palavras-Chave: Silenciamento; autonomia; ficção portuguesa contemporânea; Julieta Monginho. 


\section{Abstract}

The work proposes a reading of the novel A terceira mãe (2008), by the Portuguese writer Julieta Monginho, from the perception of a movement that goes from silencing to female autonomy. Following the trajectories of mother, daughter and granddaughter, the author intertwines three different generations of women in contexts throughout the XX-XXI centuries. Connected by blood and experiences, the three characters form the focus of the narrative plot, with a special focus on the figure of the first mother, Rosalina. Thus, from the silence imposed on the mother / grandmother, by socio-political factors, to the autonomy of the granddaughter, Joana, the novelistic fabulation weaves the trajectories of these three Portuguese women.

KEYWORDS: Silencing; autonomy; contemporary Portuguese fiction; Julieta Monginho.

Há o álbum das fotografias e os espelhos que devia ter mandado arrancar quando percebeu que lhe arrancariam tudo, mesmo o mais leve sinal do que teria podido ser quando crescesse. Teria mandado arrancar, se soubesse exercer autoridade. Teria partido, se os estilhaços não trouxessem à vida outra desgraça. Teria protestado, se suportasse o barulho de viver. (...) Agora senta-se à janela, no lugar que a filha lhe indicou. Cada conta do rosário é o passo seguinte ao primeiro passo que um dia, quem sabe, ainda há-de dar (MONGINHO, 2019, p.47-48).

É também esta ideologia assente na "natureza" que legitima a norma segundo a qual a vida sexual das mulheres deve circunscrever-se à conjugalidade e à reprodução. Se à mulher é reservado o papel de esposa, mãe e "fada do lar", como se deduz das próprias palavras de Salazar, então, é em torno destas finalidades que todas as restantes dimensões da vida feminina devem decorrer (POLICARPO, 2011, p. 51).

Publicado em 2008, e praticamente desconhecido do público brasileiro, o romance $A$ terceira mãe, da escritora portuguesa Julieta 
Monginho', acabou por se constituir no próprio ápice da trajetória de sua autora. Galardoada com o Grande Prémio de Romance e Novela da APE (2008), a obra destaca-se não só pela sua envergadura temporal, ao incorporar três gerações de mulheres ao longo dos séculos XX e XXI, mas, sobretudo, pela aposta pertinente em representar, a partir de suas protagonistas, cenas familiares de figuras femininas e suas tensões dentro das redes de parentalidades.

Como bem alerta Dionísio Vila Maior, há no bojo narrativo da obra de Julieta Monginho uma preocupação que extrapola a simples exposição geracional, exatamente porque A terceira mãe, "mais do que abarcar a história de três gerações de uma família, trata(-se), essencialmente, da história de três mulheres: Rosalina, a filha Filomena e a neta Joana" (VILA MAIOR, 2017, p. 53-54).

Já aqui vale ressaltar que o tema das células sociais familiares não constitui um aspecto desconhecido no conjunto de textos da autora ou isolado exclusivamente na obra de 2008. No seu terceiro romance, À tua espera (200oa), o leitor é convidado a acompanhar a trajetória de David e João, pai e filho, numa espécie de viagem aventurosa, um verdadeiro "macrocosmos caprichoso", marcada por "solavancos narrativos" (MONGINHO, 200oa, p. 21), cuja "multiplicidade de dimensões excede a de qualquer sólido geométrico" (MONGINHO, 2000a, p. 23), como bem elucidará o narrador.

Também em Dicionário dos livros sensíveis (2000b), obra tecida sob o signo da fragmentaridade, os conflitos e as tensões familiares surgem ora em verbetes explícitos, como sucede em "Filho" e "Mãe",

1 Trata-se do sétimo romance da autora, tendo como obras antecedentes Juízo perfeito (1996), A paixão segundo os infiéis (1998), À tua espera (200o - Prémio Máxima de Literatura, 200o), Dicionário dos livros sensíveis (2000), Onde está J.? (2002) e A construção da noite (2005). Após a premiação de A terceira mãe (2008), a escritora ainda publicou António, Maria (2010), Metade maior (2012) e Um muro no meio do caminho (2017 - Prémio Fernando Namora, 2019). 
por exemplo, ora em verbetes indiretos, dentre os quais "Diálogo (em 1996)" se destaca como um caso pontual, onde o teor aforístico intenta reintegrar a concepção das dissonâncias parentais a partir da articulação de imagens metafóricas: “- O que é a família? - É uma mesa com cadeiras à volta" (MONGINHO, 200ob, p. 28).

Ora, essa última imagem parece-nos muito sugestiva para compreender a dimensão dos laços familiares efabulados ao longo da trama de A terceira mãe. Como numa espécie de cadeiras à volta de uma grande mesa, pode-se pensar, no núcleo familiar de Rosalina, a figura da avó como eixo central, espécie de força centrípeta, enquanto Filomena, ou Mena (a filha), e Joana (a neta) são as que vivem sempre numa relação dialógica com a figura da mãe/avó. Outras personagens acabam compondo o quadro das relações sociais e afetivas da protagonista principal (as irmãs, os irmãos e os pais de Rosalina, tia Alice e tio Celestino; Hipólito, o primeiro marido, e Luís, o primeiro filho de Rosalina; o enteado que se suicida, dentre outros), em um cruzamento temporal entre os séculos XX e XXI em Portugal, época demarcada no romance pelos ecos vindos do autoritarismo do Estado Novo e dos rumores da II Guerra Mundial, chegados sempre aos fragmentos; pela redemocratização celebrada, graças à Revolução dos Cravos (1974), e pelos questionamentos e incertezas, característicos das jovens gerações surgidas num cenário globalizado e altamente tecnológico.

Assim, numa arquitetura narrativa muito bem urdida, a sequência da ação romanesca obedece diacronicamente o respectivo surgimento das personagens, porém, em cada núcleo geracional, o tempo vai sendo costurado de forma fragmentada, com inserções polifônicas de outras personagens (como ocorre no primeiro bloco, cujo centro é Rosalina, a avó), com digressões da própria voz narrativa (como sucede na parte central, narrada por Maria Filomena) ou de um narrador heterodiegético (como se apresenta a última parte, destinada à neta Joana). 
Ou seja, no seu conjunto, tal como o título da obra parece aludir (A terceira mãe), cada uma delas vai desempenhando a seu modo os papéis de uma maternidade muito particular, ora concretizada (em Rosalina e Mena), ora sugerida de forma simbólica (em Joana).

Durante toda a trajetória da primeira personagem feminina - a avó Rosalina -, as cenas privadas focam na subalternidade compulsória delegada às mulheres da família. Separada dos seis irmãos aos quatro anos de idade para viver com a tia Alice e o tio Celestino, Rosalina já é informada de que sua vida não teria escolhas, pelo menos não por ela própria, mas deveria seguir os paradigmas pré-concebidos e esperados de uma mulher digna de família. Deste modo, Lina é criada na "Casa de Colmo”, recebendo educação artística e linguística e desenvolvendo, ao mesmo tempo, a sua capacidade de criação pela música e pela pintura:

Aos quinze anos, Rosalina falava francês, tocava valsas no piano. Chamava-se menina Amália a professora de piano e de francês que lhe ensinava a Sonata ao Luar e o Danúbio Azul, Corneille, Racine e Molière. O tio Celestino ouvia, surdo, fardado de capitão do exército. Usava um boné e galões dourados sobre a cinza que ele era, farda de si próprio. «Rosalina, mostre as suas mãos. Palmas para baixo, palmas para cima. Apresentaaaaar MÃOS.» As mãos de cera, confundidas com armas. (...)

Desde que pintara uma andorinha primaveril numa fita encarnada, a pedido de um primo, para a queima das fitas, Rosalina tinha ganhado apego a pintura sobre seda, como se inventasse um alfabeto alado. Quando se apanhava sem o marido, a tia Alice ia a correr comprar-lhe as fitas à loja do senhor Atouguia, na arcada da Praça do Giraldo. Da ponta do pincel nasciam borboletas, gaivotas, toutinegras, tudo o que voasse. Ao fim da tarde, Rosalina esfregava os dedos com pedra-pomes até ficarem imaculados. (...) Dedos esculpidos para sonhar, com eles pintava asas e riscava dias num calendário feito de fugas para cidades invisíveis, todas nome e infinito (MONGINHO, 2019, p. 13-14). 
Já a partir das informações cedidas pelo narrador, Rosalina vai sendo construída, sob o signo do anseio da liberdade, do sonho, do voo e das vontades não realizadas, em virtude da obrigatoriedade dos papéis submissos a que a mulher estava destinada a cumprir. Ora, essa ausência de autonomia surge, na arquitetura textual, nos momentos em que o narrador empresta sua voz aos que convivem ou conviveram com Rosalina, e esses, por sua vez, apresentam suas impressões e fazem declarações acerca da protagonista, que vai percebendo todas essas mensagens ao seu redor, mas que, sem força para romper com a corrente de subserviência a que ela própria foi treinada e sem compreender muito bem como reagir aos ditames sociofamiliares, “(...) ela abanava a cabeça com um sim, mas continuava calada com um não" (MONGINHO, 2019, p. 10).

Interessante observar que as passagens referentes à Rosalina representam o que a personagem vive durante a trama narrativa. Não à toa, todo o primeiro bloco do romance, intitulado "Rosalina", ocupa mais da metade da extensão da obra, sem que, em momento algum, ela própria assuma a voz narrativa. Ainda assim, Rosalina surge como a primeira das três mães e a figura central da obra. E quando utilizamos o termo central para designar Rosalina, não se trata apenas de reiterar a importância que a autora e/ou narrador quiseram destacar, mas também configurar a relevância e a centralidade da protagonista em relação às demais personagens do romance. Isso fica evidente, por exemplo, quando os capítulos contendo a inclusão de outras vozes autônomas invadem a narrativa sobre Rosalina, sempre nomeados a partir das relações estabelecidas com a avó: "A filha” (de Rosalina), “A neta” (de Rosalina), “O marido” (de Rosalina), "O vizinho" (de Rosalina), e assim por diante.

Vale esclarecer, aqui, que, ao compor a sua criatura inserida num contexto de subserviência e obediência cega a um poder masculino e autoritário, não deixa a autora de revelar os lados cerceadores da au- 
tonomia e da liberdade femininas. Nessa perspectiva, Tio Celestino, militar da reserva e explícito apoiador do Estado Novo Salazarista, que "se curvava todo, à voz do Presidente do Conselho e à de Sua Eminência Reverendíssima" (MONGINHO, 2019, p. 29), surge como uma figura controladora da ordem, capaz de vigiar as atividades da sobrinha e de lhe tolher qualquer tentativa de fuga desse enquadramento.

Daí que esse maior espaço concedido à Rosalina, na arquitetura romanesca, não significa idealizar uma romantização da luta da personagem, muito menos propor a sua performance como uma solução adequada a anseios e desejos inalcançáveis. Na verdade, Rosalina representa a mulher silenciada, que chega até a cogitar uma voz, mas não faz ideia de que exista uma possibilidade de exercê-la. Logo, como poderia reivindicar algo do qual não sabe a existência?

Acreditamos que o narrador, ao longo das exposições em torno dessa personagem, não teria outra saída a não ser vocalizar em terceira pessoa, falando sobre e por Rosalina. Em uma narrativa totalmente fragmentada e polifônica, porque as vozes das outras personagens invadem o núcleo efabular destinado a avó e "falam" na primeira pessoa, Rosalina será a única sem a capacidade de gerir, administrar e produzir a sua própria narrativa ao longo da trama. Logo, os apontamentos de um narrador heterodiegético, os depoimentos das outras personagens e mesmo as impressões do leitor serão os únicos instrumentos possíveis de compor a natureza subjetiva da protagonista.

Por isso, a nossa aposta reside em compreender Rosalina como uma representação da figura da mulher no período do Salazarismo, tal como elucida Cláudia Casimiro. Segundo a investigadora portuguesa:

A ideologia dominante e conservadora que vigora durante o regime de Salazar impõe publicamente a noção de que Portugal é povoado por famílias felizes, ordeiras, trabalhadoras e pacatas. Insistentemente, e por todos os meios (incluindo do ponto de vista jurídico) é difundida a apologia da mulher "esposa”, modesta, 
“maternal”, submissa, com um papel expressivo no seio da família: a prestadora de cuidados cuja principal ocupação consiste em cuidar da casa, qual boa "fada do lar". A mulher era vista como o elemento que unifica e concilia e que deve auxílio e obediência ao marido (CASIMIRO, 2011, p. 113).

Interessante observar que Rosalina, em certa medida, até tenta se encaixar nesse modelo estabelecido de “apologia da mulher 'esposa', modesta, 'maternal', submissa, com um papel expressivo no seio da família" (CASIMIRO, 2011, p. 113), e que efetivamente ela tem. No entanto, há um embate interior travado entre essa força externa sócio-política e a sua interioridade sedenta por outros horizontes. Tanto assim é que, mesmo consciente do papel social que deveria desempenhar, ela não deixa de sonhar com uma autonomia e uma liberdade de movimentos e de vontades, a que o revoar dos pássaros e das fitas coloridas sempre irão evocar, dialogando inclusive com outras imagens femininas paradigmáticas nesse anseio libertário:

Uma noite, reparou que não sentia dores e que ninguém roncava ao seu lado na cama. Para celebrar a surpresa, empurrou a almofada para o centro e dormiu manhã fora, sonhou que estava sentada no ramo de uma árvore a cantar o "L'Amour", puxando as pontas do vestido ate se verem os botins e as meias negras de Carmen.

Os pássaros voavam continuamente. Desenhava-lhes as asas, as vezes só duas pinceladas negras que voavam, nódoa negra sobre o azul. Voava, ficava no pano, nódoa, lágrima. Inchava, a gaveta onde guardava as fitas que podiam prender, ataras mãos, amarrar ocabelo. apequenar os pés ate sangrarem como os de uma gueixa. Ou então levarem-na com o vento a dar a volta ao mundo. (...) Cantava, o pássaro, quando Rosalina lhe fazia cócegas nas penas. Cantava "L'Amour", como ela cantara no primeiro sonho livre. Foi para cantar essa ária que o desenhou (MONGINHO, 2019, p. 24). 
Devassando a intimidade dos espaços habitados pela personagem, o narrador vai revelando os mais íntimos pensamentos de Rosalina, de uma forma muito cúmplice com os seus sonhos de liberdade, representados pelos pássaros e pelas imagens oníricas fugidias. Ainda que o primeiro casamento com Hipólito tenha sido realizado sem o seu consentimento, mas dentro daquelas premissas exigidas e dos trâmites tradicionais da época (CASIMIRO, 2011), a personagem parece não compactuar com essa prática cerceadora dos desejos da mulher, tanto que, em muitos momentos, ela irá se sentir desconfortável. Daí a nossa aposta de compreender Rosalina como uma figura marcada, a princípio, por uma inquietação, ainda que tímida e silenciada, ou, como, na feliz expressão de Dionísio Vila Maior, um "lugar de desassossego quase permanente, cujos sonhos vão sobrando nas asas que vai pintando em fitas de seda" (2017, p. 58).

Quando ressaltamos, anteriormente, que a protagonista não deve ser entendida pelo viés de uma idealização romantizada, isto ocorre porque Rosalina tem plena consciência das regras que regem o mundo e, parcialmente, concorda com elas. Não gratuitamente, na cena anterior, ao se dar conta de que se encontrava sozinha no leito conjugal, diante das fugas e das traições de Hipólito, a sua saída foi exatamente imaginar-se fora daquele espaço, evadindo-se para um outro, onde o voo dos pássaros e o canto da ária da ópera Carmen ${ }^{2}$

2 Ópera do compositor francês Georges Bizet (1838-1875), Carmen (1875) é baseada no romance homônimo de Prosper Mérimée, com libreto de Henri Meilhac e Ludovic Halévy. A trama central gira em torno de uma cigana, que seduz o alferes D. José, na saída das cigarreiras numa praça em Sevilha. Exatamente nessa cena, no Ato I, que a protagonista canta a Habanera ("Lamour est um oiseau rebelle" / "O amor é um pássaro rebelde”), que enfeitiça D. José. Momentos depois, numa briga na fábrica de cigarros, Carmen é acusada de agredir uma das companheiras. Diante da possibilidade de ser presa, a cigana seduz o militar a fim de que este a liberte e ambos fujam. Completamente apaixonado por Carmen, D. José abandona a mãe e sua noiva Micaella, para fugir com o bando de 
despontam como os únicos instrumentos possíveis para alcançar uma plenitude, já que esta, no plano físico, era impossível.

O tempo de Rosalina é, portanto, o tempo do Estado Novo, período no qual as mulheres estavam predestinadas a um papel doméstico, de submissão plena e impedidas de exercer algum tipo de função importante, a não ser a administração do lar (CASIMIRO, 2011; MELO, 2017). Na trama, essa situação surge ao longo do percurso da personagem, na medida em que o seu primeiro casamento é realizado quando ela ainda era uma adolescente de 16 anos. Lina casa-se com um desconhecido que aparece repentinamente na casa dos tios para a desposar. No dia da apresentação de ambos, Rosalina não tem o direito de falar e, diante de um sol dourado ofuscando seu olhar para o futuro esposo, a única possibilidade de vocalização é o seu "sim", diante do pedido do pretendente. E, assim, o seu primeiro casamento padece diante da falta de sintonia e de comunicação entre Rosalina e Hipólito.

Todo este cenário social revisita de forma muito coerente as uniões nupciais de Portugal, nas décadas de 1940-1950, pois, como bem esclarece Helena Pereira de Melo:

"a idade nupcial é definida em termos desiguais pelo legislador: dezasseis anos para os rapazes e catorze para as meninas, embora

ciganos. No entanto, nesse interim, no bar Lillas Pastia, a protagonista conhece e sente-se atraída por Escamillo, um toureiro que chega para uma disputa na arena em Sevilha, e que lhe declara amor publicamente. No final, consumido pelo ciúme, ao ver Carmen com Escamillo na praça de touros, D. José tenta convencer a cigana a abandonar o rival e ficar com ele. Diante das insistentes negativas de Carmen, que defende a sua posição de mulher livre para escolher o seu amor, D. José apunhala a cigana e termina com o corpo de Carmen nos seus braços, diante dos olhares horrorizados da população. Mais detalhes sobre a composição e aspectos da construção da trama operística, consultar a obra de Lauro Machado Coelho (1999). 
a incapacidade por menoridade só cesse (salvo em caso de emancipação por casamento) aos vinte e um anos em ambos os sexos" (MELO, 2017, p. 65).

De um lado, portanto, enquanto o poder controlador sobre as vontades da adolescente Rosalina no espaço da "Casa de Colmo", com os gestos de tia Alice e a voz vigilante e cerceadora de tio Celestino acabam por interferir na construção da protagonista, como mulher portuguesa no contexto do Estado Novo; de outro, a infelicidade e o abandono do primeiro marido prefiguram o vaticínio sobre os destinos femininos, entendidos como incapazes de escrever as suas próprias histórias e desenhar os seus destinos.

Vale recuperar, mais uma vez, a voz lúcida de Cláudia Casimiro, ao descrever o panorama histórico e político português desse período, onde,

Durante os anos em que vigorou o Estado Novo, imperava a ideia de que à mulher cabia sacrificar-se em proveito da família. Apoiada na religião e na fé católica, esta deveria aceitar o destino de Deus, resignar-se perante a dor e as penas que lhe coubessem suportar. Por exemplo, um marido que lhe fosse infiel ou bebesse demasiado ou usasse contra si algum tipo de agressão: física ou psicológica. (...) O papel feminino era o de glorificar a maternidade e garantir a estabilidade e a harmonia familiar: salvaguardar a "moral das famílias" fosse sob que condição fosse (CASIMIRO, 2011, p. 117).

Exatamente neste contexto, tirada dos pais, imposta às aulas escolhidas pelo tio, proibida de fazer a única coisa que realmente gostava e levada ao altar para ser entregue a um homem que nem conhecera, a trajetória dessa primeira mãe, de três gerações de mulheres, e sua intimidade vão sendo devassadas por um narrador que não se afasta de Rosalina e, em muitos momentos, assume uma cumplicidade com os sonhos e os anseios da personagem. 
Ainda que as fatalidades das traições e da morte do primeiro marido e do filho deste casamento ("Luis, o menino peixinho"), do suicídio do enteado de Rosalina e do câncer de Vitor, seu segundo esposo, que a faz encarar a viuvez pela segunda vez, apontem para essa resignação de dor e de pena, esperada da sua condição de esposa e mãe, o narrador não deixa de compartilhar os momentos cruciais de Rosalina, a ponto mesmo de revelar que a continuidade da sua história não foge do caminho pré-estabelecido pela ordem estadonovista, na medida em que ela tem filhos, perde o primeiro marido, casa-se novamente, vê o seu enteado suicidar-se e o segundo marido perder a luta contra uma doença que o definha. Deste segundo casamento, nasce Maria Filomena, a filha que receberá destaque na narrativa, $\mathrm{e}$ esta tem Joana, a neta.

No seu conjunto, a trajetória de Rosalina desnuda algumas situações que revelam também a sua interação com o status quo estabelecido, no contexto do Estado Novo. Basta observar, por exemplo, a sua plena aceitação ao receber o ensinamento de tia Alice, além da vigilância acirrada de tio Celestino e da impossibilidade de reação diante dos desmandos. Desde cedo, portanto, é ensinada a seguir ordens para não sofrer punições, e assim a protagonista cresce, amadurece e vive o restante de sua vida com os ecos e as ressonâncias dessa educação conservadora.

No entanto, é a partir do segundo casamento, com Vitor, que a personagem começa a abrir os olhos e tecer uma nova percepção da realidade à sua volta, seja num âmbito espacial micro, compreendendo a sua casa, os seus vizinhos e a vida política do país; seja numa dimensão macro, envolvendo a Europa e o mundo:

Salário. Inferno. Camarada. As palavras que ele trazia. Rosalina acolhia-as e amava-o, como quem abre as mãos a uma abelha, olhando só ao mel. Não era um dom da natureza, mas uma inclinação peculiar: Rosalina olhava cada coisa como ser e de cada ser conhecia apenas a secreta luz; quando não existisse, o olhar desenhava-a, torna- 
va-a coisa viva. Assim lhe desenhava a boca e as palavras transpostas para a língua. Palavras severas, nunca sussurradas. Palavras contra. Nenhum acordo com o mundo, nenhuma trégua. Pó, suor, palavras sós e duras, sangue, hoje após hoje após hoje, mesmo se os amanhãs cantassem na voz do grevista sem medo dos bastões da polícia (...)

Viva! Se uma cadeira podia derrubar um ditador e reanimar um povo morto, qualquer prodígio podia acontecer. Por exemplo, chegarem pela primeira vez homens à Lua. E se fossem espreitar o televisor para ver se a notícia aparece? A Mena carregou no botão e zás, o milagre em directo. Lá está ele, o astronauta na sua cândida leveza, one small step for man, one giant leap for mankind. Rosalina sempre imaginou que, ao dizer estas palavras, Neil Armstrong sentia as pernas crescerem como as de um gigante verdadeiro. $\mathrm{Ou}$ talvez estivesse apenas atordoado pelo calor e pela novidade da vida, como ela (MONGINHO, 2019, p. 67 e 99).

O mais instigante nessa percepção de Rosalina é que, ainda sob o impacto daquilo que recebeu como forma de se expressar como ser humano e como mulher, a personagem não consegue esboçar uma reação de autonomia, mesmo diante da constatação das mudanças do país (a queda de Salazar da cadeira) e das conquistas tecnológicas do mundo (a chegada do homem à lua). Ou seja, os ensaios de uma revolução e os passos livres na conquista de espaços desconhecidos ainda não são suficientes para Rosalina assumir a voz narrativa $e$ conceber a sua própria narração.

Malgrado a ausência de uma emancipação da sua voz, enquanto instância narrativa e geradora de uma narração própria e autônoma - ao contrário do que sucede em "Mena” e com as inserções da neta Joana -, Rosalina é capaz de vivenciar o amor na relação conjugal. E, ainda que o seu segundo casamento não possa ser designado como uma relação completamente fraturante das convenções familiares, não deixa de ser sensível à ruptura estabelecida com os papéis puramente subalternos a que a mulher estava condenada. 
Muito diferente da união com Hipólito, a sintonia com Vitor, seu segundo marido, dá a Rosalina uma nova visão de mundo e uma percepção mais aguçada dos principais eventos que demarcam as novidades e as alterações nos rumos da própria humanidade. Trata-se, no nosso entender, de uma aprendizagem feita pelo olhar e pela percepção da realidade sócio-política, sem, no entanto, abrir mão das afinidades afetivas marcantes na relação amorosa de ambos.

Ou seja, na contramão da subalternidade imposta por Hipólito, com Vitor, Rosalina pressente a reciprocidade amorosa, experiência por si só libertária, porque abre diante dos seus olhos um horizonte de sentimentos nunca antes experimentados. Não à toa, no momento da sua segunda viuvez, o narrador cola-se à perspectiva da personagem e deixa fluir uma série de emoções represadas e as fornece ao leitor, num gesto de cumplicidade:

Rosalina não era a viúva. Nem lhe passou pela cabeça ir pela roupa preta. Ela era a mulher que perdera o seu homem, o mundo deixara de estar ali, existiria talvez na cabeça de alguém, mas não na sua. Quando o marido respirou pela última vez, não foi a alma que se afastou, essa ia ficar. Rosalina não a imaginava entre as almas eleitas, não por falta de mérito, mas porque se sentiria sempre envergonhada no meio das outras e preferia habitar o pensamento da mulher. $O$ que abandonou o marido e a abandonou a ela foi toda a superfície do tacto. Não se suporta a vida sem tocar no corpo amado. Quando o marido respirou pela última vez, foi toda a superfície dele que se arrancou da superfície dela, que a amputou da parte de si que às vezes se aquietava. Sentiu o golpe, um arpão a furar-lhe as entranhas e a removê-las (MONGINHO, 2019, p. 157).

Na verdade, esse ensaio de libertação só irá aparecer com a presença da filha Filomena, sobretudo, quando esta se coloca em nítido confronto com a mãe, em tom desafiador e rebelde, referindo-se às pinturas que Lina voltara a fazer como mera tentativa de sonhar algo que não conquistara: "Mãe, ouve-me bem, as pessoas não voam. 
Ninguém consegue voar, percebestes? As asas que tu pintas não servem para voar, não servem para nada" (MONGINHO, 2019, p. 30.). Ou ain$\mathrm{da}$, sob a perspectiva do narrador, que relata: "Rosalina assistia a tudo. Assistia todos. Que mais podia fazer?" (MONGINHO, 2019, p. 150).

Muito diferente da trajetória da mãe, Filomena surge como um início de ruptura, mas que não se realiza plenamente. Filha dos anos de 1960, da década em que os primeiros e mais sutis passos para uma improvável transformação são dados, Maria Filomena tateia uma espécie de resistência, sobretudo diante da consciência que tem da fatalidade acerca do destino da mulher durante o período do Salazarismo. Se a publicação da Carta a uma portuguesa, em 1961, e a efetiva comercialização da pílula contraceptiva nas farmácias portuguesas ocorre a partir de 1962, não podemos ainda configurar nesses atos a deflagração de uma liberdade conseguida por parte dos movimentos sociais e feministas em Portugal (POLICARPO, 2011)

No nosso entender, a passagem por este cenário acaba por aumentar as diferenças entre as duas mulheres. Por um lado, a mãe ainda não se desvencilha do antigo modelo, por outro, Filomena compreende que Rosalina assume o silêncio da imposição estadonovista, para que a família, parte da engrenagem social, pudesse, pelo menos, aparentar uma normalidade, não sem almejar, mesmo que na interioridade das expressões, voos de liberdade e de autonomia, nos desenhos e nas fitas coloridas que cria.

3 O estudo de Verônica Policarpo (2011) é pontual e cirúrgico nesse ponto. Por mais que alguns acontecimentos apontem para um ensaiar revolucionário, a vida familiar portuguesa ainda encontrava-se regida por padronizações pré-estabelecidas, que só seriam revistas e questionadas depois do 25 de abril de 1974.* Segundo ela, nas décadas de 1950 e 1960, a "preponderância das instituições sociais, como o casamento, a família, ou até 'a nação' sobre o indivíduo e seus interesses, leva-nos a falar de uma subordinação do indivíduo ao grupo, em matéria de sexualidade" (POLICARPO, 2011, p. 57). 
Não à toa, portanto, o romance A terceira mãe dedica mais da metade de sua estrutura ao percurso de Rosalina, posto que, somente passando por ela, as duas gerações sucedâneas poderiam ensaiar e viver os tempos da revolução (a filha Mena) e, também, assumir o controle de suas escolhas, dos seus atos e dos seus caminhos (a neta Joana). Logo, a construção da obra em três partes segue uma linha cronológica diacrônica, costurando os destinos da avó (Rosalina) com a filha que se torna mãe (Filomena) e a neta que sela essas três gerações de mulheres (Joana). São, portanto, três partes que se completam, e cada uma delas reflete sobre as outras as três personagens citadas.

De Rosalina a Mena, a narrativa encena a chegada da Revolução dos Cravos, evento que demarca a queda do Salazarismo, em 1974, e anuncia novos tempos para Portugal. Se a primeira assiste tudo com um assombro quase incontido, a segunda vive os sentimentos de esperança e de mudança trazidos pelos cravos dos capitães de abril. Ao articular suas duas criaturas, Julieta Monginho não deixa de mostrar como as personagens femininas reagem a esse novo mundo:

Rosalina não queria deixá-lo ali sozinho, mas também queria ir a correr para o televisor ver as imagens da festa na rua. (...) Erguê-lo demorou cerca de dois dias, mas valeu a pena voltar a casa, porque as imagens na televisão davam a Rosalina vontade de cantar com elas e de espalhar ao vento os últimos pássaros, presos nas fitas de seda. Como se invadissem saudades de uma alegria qualquer que não se lembrava de ter tido (MONGINHO, 2019, p. 120-121).

Ainda que os sentimentos de Lina acolham uma condição de expressão contida, porque tudo assiste do lado de dentro da casa, há de se destacar a duplicidade emotiva por ela experimentada, ao abraçar ainda o papel de cuidado e zelo do marido e, ao mesmo tempo, desejar cantar a liberdade e desprender "ao vento os últimos pássaros, presos nas fitas de seda”. Por outro lado, Filomena, diferente da mãe, é aquela que assume a transição de mudanças de tempos e 
de comportamentos. A reação desta aos gestos da mãe rasura uma suposta predisposição que, enquanto filha e mulher, não consegue aceitar, porque se coloca de forma rebelde aos mínimos detalhes, como uma maneira de resistir à conformidade e ao conservadorismo dos tempos antigos:

O nome da vontade. Dei às minhas filhas nomes afirmativos, nomes que lhes assegurassem um lugar muitos palmos acima do chão. Tu chamaste-me Maria Filomena, é nome que se ponha? Ficaste toda orgulhosa da façanha, sem a mínima ideia do que um nome pode mutilar. Quando eu tinha onze anos, leste-me o livro e eu soube que o meu destino não era ser virgem e mártir como Santa Filomena. O meu ser era não ter destino algum. (...)

Dei às minhas filhas nomes que lhes asseguram um lugar no mundo. E ela aí foi, a mais velha voou. Os pássaros não voam, as pessoas não voam, as filhas sim. Dizem que anda perdida. $\mathrm{Na}$ polícia não me ligam. Mas eu sei que o mundo a encontrou porque ela procura procura e procura o caminho e há-de encontrar uma vereda qualquer. Eu estou tão velha que já não procuro nada. Muito mais velha do que tu. (MONGINHO, 2019, p. 30).

A oposição de Mena em relação à mãe fica visível logo na expressão da voz narrativa que assume uma autodiegese. Com sua voz, Mena narra as suas inquietações, sobretudo, as diferenças entre elas no uso dos nomes para as filhas e o pragmatismo em perceber que somente o ser humano é capaz de criar os seus mecanismos de liberdade e autonomia. São essas forças, aliás, que movimentam o seu discurso, a ponto de defender que a compreensão temporal de ambas é muito distinta. Assim, enquanto Rosalina é aquela que passa pelos tempos sem deixar que o seu corpo expresse as suas marcas e cicatrizes, Filomena é a que tudo vivencia até às últimas consequências, consumindo-se numa velhice precoce, a ponto de se sentir muito mais madura que a mãe. 
Nesse sentido, Mena é a personagem que não aceita o silenciamento total, não se curva às normatividades e à subalternidade que a sua mãe aceitara. Em contrapartida, ela também não obtém êxito em suas escolhas, porque essa insatisfação fica apenas no plano do sentir. Talvez, exatamente por se tratar de uma personagem transitiva (dos tempos da ditadura aos da redemocratização), ela carece de ajustes para viver num mundo onde seja possível fazer escolhas, mas Mena é a primeira dessa tripla geração feminina de mães a viver essa experiência.

Ao que tudo indica, por não obter sucesso, ela precisa reivindicar sua vitória num outro triunfo que lhe cabe: o poder de vocalizar a narração em primeira pessoa. Por isso, o julgamento à mãe e ao mundo de maneira geral passa por uma tonalidade ácida, pois, ao contrário de Rosalina, que se contentava em "desenhar asas e balões sobre o seu corpo e nunca mais sentir o chão" (MONGINHO, 2019, p. 134.), a preocupação de Filomena não estava em habitar em paragens oníricas, mas experimentar as coisas, mesmo que numa brevidade de tempo: "Quanto mais penso nas coisas mais elas têm tendência para degenerar e morrer. Quero dentro de mim as coisas vivas. Nunca como um sonho, só como um sentir mais breve" (MONGINHO, 2019, p. 145; grifos nossos).

Do silenciamento de Rosalina à vocalização autodiegética de Filomena, instaura-se entre essas duas mulheres, essas duas mães, uma mudança de reações, posto que, diante das experiências familiares e mundanas, sai-se de um aprendizado pelo olhar (de Rosalina) e passa-se para um aprendizado pelo sentir (de Filomena). Conforme frisamos anteriormente, essas mulheres estão interligadas tanto pelo sangue, quanto pelas suas experiências de mundo. No entanto, do silenciamento ao pressentimento, a autonomia só será plenamente atingida com a inserção de Joana, neta de Rosalina e filha de Filomena: 
- Eu não percebo nada, já sabia, não percebo as casas, não percebo esta casa, não percebo o teu modo de viver. Como a minha avó Rosalina, não percebo que empurra e puxa para dentro deste mundo. - Joaninha, por favor, a cena da vítima não, tudo menos isso.

- A cena? Cena? Se alguém é actor aqui não sou eu, histérica também não, histérica é a minha mãe. Eu não sou a minha mãe (MONGINHO, 2019, p. 114).

No diálogo acima, travado com o namorado, Joana já revela a sua face revolucionária, porque não se inibe diante de possíveis forças de cerceamento, sobretudo, se essas partem da própria célula familiar, e faz questão de reivindicar a sua autossuficiência e emancipação. Ainda que, em nenhum momento, elas se excluam completamente, não deixa de ser curioso o fato de a neta revelar os laços indissociáveis com a avó e com a sua maneira singular de ver e perceber o mundo. Não será esta uma forma muito particular da autora Julieta Monginho propor, na composição dessas três personagens femininas, maneiras distintas de representar três gerações de mulheres, capazes de enfrentar situações parecidas, mas em diferentes contextualizações sócio-históricas, e como elas articulam seus respectivos aprendizados diante das convivências familiares e das situações político-sociais?

Se levarmos em consideração a postulação de Dionísio Vila Maior, para quem o narrador de A terceira mãe instiga "constantes reflexões sobre a condição da mulher no reservado espaço familiar e no (não tão visível) espaço social" (VILA MAIOR, 2017, p. 54.), então, é com a presença de Joana que as atenções se voltam não para a repetição de laços familiares construídos sob o signo da subalternidade feminina ou da sensitividade momentânea e efêmera do presente. Joana vive um momento em que precisa fazer escolhas, e quanto mais adia as suas decisões, mais difícil se torna tomar uma atitude. Nesse momento, o narrador revela a impetuosidade da neta de Rosalina, que é capaz de transformar a subalternidade discursiva da 
avó e do sentir momentâneo da mãe em gestos de uma experimentação autônoma e independente:

Como não tinha medo, não era preciso decidir logo, tinha era de aprender caminhos. Desceria da cama, pegaria na mochila, pé ante pé encontraria a saída contornando todos os obstáculos, bicos de pés sobre os tapetes, os corredores intermináveis, devagarinho iria abrindo as portas até à que abre da cozinha para o quintal. De cabeça erguida sairia pelas traseiras e acolheria o sol nascente, o cantar dos galos nas capoeiras dos vizinhos, enfrentaria os latidos dos cães de guarda e as beatas passinhando até à capelinha. Avistaria a árvore centenária e sempre sempre sempre desafiaria a sua maldição (MONGINHO, 2019, p. 131.).

Joana não sente medo, não tem pressa, porque se constitui na figura da mulher que tem tempo e pode aprender caminhos antes de os escolher. Ao contrário da avó, Joana tem opções, talvez, por isso, nessa terceira parte do romance, a alternativa em abdicar de uma autodiegese para narrar a trajetória da neta pode ser entendida como uma bem sucedida ferramenta de construção, na medida em que o não produzir autodiegeticamente a sua própria narração não significa necessariamente ausência de vontade ou manutenção de subserviência.

E tanto assim é que a voz de Joana, se não pressentida na seção narrativa em que se debruça sobre o seu percurso, no bloco intitulado "Rosalina", por diversas vezes, ela irrompe a diegese, interrompe o fluxo narrativo e tece suas próprias confissões e reflexões à avó, valendo-se de um carinhoso tratamento que pode ser compreendido como o sinal de um pacto feito de puro carinho e cumplicidade:

Mamie linda,

Quase sem dor, o meu corpo mudou e mudou a minha vida. Nunca mais vou ter medo de nada, nem mesmo de perder o Diogo.

Este é o meu pensamento agora e este é o abraço que te posso dar. 
Vês como ainda caibo no teu colo? Como deito a cabeça no teu ombro e os nossos cabelos se confundem? E as minhas lágrimas sempre acabam em riso a saltitar na relva?

(...)

Querida Mamie, nas tuas confidências falavas sempre como se a memória fosse bastante para tornar inútil o futuro. E eu sei que não te zangas se te falar dos dias que não passam, das noites indiferentes ao tempo, de um relógio que nunca bate meia-noite. Não me esqueci de nada, descansa. Mas hoje prefiro falar-te deste lugar onde não há castigo nem perdão, nem saudades nem esperança, nem hoje nem depois.

Tão protegida, sem feridas para curar, sem feridas para temer (MONGINHO, 2019, p. 96-97).

O trecho acima revela uma personagem com a capacidade de escolher, de tomar decisões e de confidenciar as suas escolhas. Na verdade, essa parece ser a maneira de Joana agradecer e dividir a liberdade alcançada. No entanto, qual o seu lugar nessa sucessão de três mulheres com três experiências distintas de vida? Rosalina e Filomena exercem efetivamente a maternidade, mas Joana não aparece nesse mesmo papel, pelo menos, não fisicamente.

Na verdade, a sugestão dá-se nos momentos finais da trama, quando, depois de fugir de casa e ir parar num local distante, Joana é abrigada por Miguel, um misterioso rapaz que logo estabelece com ela um vínculo de afinidades. Desconfiada de que Miguel pudesse ser um malfeitor ou alguém com intenções violentas, Joana fica surpresa ao descobrir que se trata do filho de um viajante excêntrico, que fazia "colecção de autógrafos de músicos, pintores, escritores, cineastas, actores, enfim, artistas de toda a espécie espalhados pelo mundo" (MONGINHO, 2019, p. 226), e de uma mulher cujo destino ele próprio ignora - “A minha mãe por aí, no ginásio ou em reunião, precisa muito de existir" (MONGINHO, 2019, p. 226). 
Enquanto aguardam a chegada de Filomena e Diogo, o seu namorado, Joana divide com Miguel suas experiências, seus relatos de vida, suas angústias e dissabores, além dos projetos e dos planos futuros. No entanto, num jogo sugerido pelo rapaz, Joana acaba por se ver enredada numa encenação em que repete o mesmo destino acometido ao enteado de Rosalina, a criança que se enforcara com as suas fitas pintadas. Nesse momento, como numa espécie de construção plástica, o narrador investe numa possibilidade de representação da condição feminina de Joana:

Joana enlaça as pontas, só um adorno, o melro continua a sorrir, afinal não custa nada. Miguel Calado, as lágrimas a pedirem-lhe mais força. Ela aperta mais um bocadinho, o nó rente ao pescoço. O sorriso de Miguel é igualzinho ao do melro feliz, a fita pintada exclusivamente para dar à luz esse sorriso. Apertou mais um bocadinho. Depois as mãos iam-se atropelando uma à outra na pressa de desfazer o laço. Joana atirou a fita para longe, abraçou Miguel com muita força.

Quando a mãe e o Diogo chegaram, viram uma Pietá tão linda como a que o artista teria esculpido. Viram uma menina sentada no chão, o cabelo solto do lado esquerdo, debruçada sobre um menino maior que ela, os braços envolvendo um corpo em paz. Joana virou a cara para eles, atónitos, parados. Levantou-se num pulo, mas antes de os abraçar avisou:

- Não vou voltar, o Miguel precisa de mim. Hoje não o deixo aqui sozinho (MONGINHO, 2019, p. 227).

Ora, como articular Joana na sequência de mães a que o próprio título do romance sugere? É claro que não se trata de uma maternidade concretizada no aspecto físico, mas não deixa de ser intrigante o laço de afinidade criado com o rapaz recém conhecido a ponto de entre eles se estabelecer um "pacto de confiança” (MONGINHO, 2019, p. 227.). Através deste, aliás, Joana é capaz de desempenhar um 
afeto de solidariedade, ao impedir que um simples jogo terminasse e se transformasse num evento trágico.

$\mathrm{Na}$ verdade, ao se colocar em favor da manutenção da vida de Miguel, desfazendo o laço insidioso com imagens que a remontavam a um passado familiar, Joana ousa reivindicar o seu espaço de autonomia e de independência, na medida em que ela própria dita o seu rumo e decide o seu destino. Não será isto uma outra forma de não obedecer a uma voz de comando masculina e rasurar definitivamente o papel de subalternidade feminina?

Acreditamos que sim, posto que, mesmo depois da viagem de retorno com o namorado e a mãe, a personagem continua tocada pela busca do seu próprio caminho. Por isso, o narrador aproxima-se desse percurso da neta de Rosalina e revela: "Joana passou um ano à procura de caminhas e às tantas estavam tão multiplicados que não lhe pareceu estranho o atalho de volta a casa" (MONGINHO, 2019, p. 230). Ainda assim, o retorno não deve ser entendido como um desfecho acabado e um ponto de chegada absoluto.

Mesmo que cada uma das personagens consiga reencontrar as suas felicidades individuais, Joana sobressai nessa sequência de três gerações de mulheres exatamente porque a sua autonomia não se configura como sinônimo de apatia, mas se revela como um indício de demanda constante por uma afirmação, que só se concretiza na dinâmica do movimento, e não no estado estático:

Joana desenhava histórias do princípio ao fim à procura de uma história inteira. Filipa continuou a espreitar a vida com lábios cor de fogo e ar desconfiado. O melro voou para longe, mas deixou o sorriso que, espera-se, nunca mais encontrará corpo em desamparo.

Diogo foi acolhido como aliado, aquele que projectava a Casa. Miguel aparecia de vez em quando e perturbava sempre a ordem. Cabia-lhe calcular as extraordinárias dimensões do mundo. Joana sentia-se bem assim, com um pé na casa e outro na viagem, os sonhos todos misturados (MONGINHO, 2019, p. 230-231). 
Por isso, a importância de Joana assenta na sua capacidade de gerir um presente de recusa da subalternidade passada e mesmo das efemeridades momentâneas. Joana é a personagem que instaura a rasura sobre a subserviência feminina diante da imposição masculina, porque busca e olha para fora e para longe, sem abrir mão da sua voluntariedade. Ela, por fim, não deixa de ser uma autêntica personagem feminina do romance pós-Estado Novo, mas não a que vê esse regime cair, mas aquela que ouve falar sobre o período e deste não tem qualquer nostalgia. Outrossim, Joana reverbera as novidades daquele "modelo mais moderno, assente numa maior individualização da sexualidade, numa maior possibilidade de o sujeito fazer as suas escolhas em liberdade" (POLICARPO, 2011, p. 6o). Por isso, a iniciativa de morar com Diogo, o namorado e a sua movência em viajar, conhecer novos lugares e expandir os horizontes podem ser entendidas como algumas daquelas "extraordinárias dimensões do mundo", que configuram a diferença e a singularidade da personagem.

Obviamente, quando se pensa em Joana, enquanto criatura ficcional da trama de A terceira mãe, imagina-se que ela deveria ter um destaque maior até do que Rosalina, o que não chega a ser propriamente uma solução adequada. Isto porque Rosalina reverbera um passado de subalternidade e silenciamento, cuja memória precisa ser reativada de forma analítica e crítica, do mesmo modo como Filomena representa uma transição difícil, porém necessária. Se Joana ressoa um presente por construir na dinâmica das buscas, não se poderá negar que, reunida com Rosalina e Filomena, aponta sugestivamente para uma ressignificação do passado, bem como para uma amostra da luta e um desfecho esperançoso.

Ao reunir a avó, a mãe, a irmã Filipa (que, na narrativa, não desempenha um papel de relevância nas histórias particulares das mulheres dessa família), o namorado Diogo e o jovem Miguel, Joana reconhece as instabilidades dos espaços familiares, mostrando uma 
naturalidade na convivência com as harmonias e as dissonâncias que cada um dos seus membros traz consigo. Ela constitui-se, por fim, como a personagem responsável por instaurar um aprendizado pela experimentação pessoal e intransferível.

No fundo, cada uma das personagens, ao seu modo, carrega as suas inquietações e necessidades, por isso, o romance $A$ terceira mãe, de Julieta Monginho, pode ser entendido como uma daquelas "narrativas de demanda" (SAMPAIO, 2005, p. 551.): demanda pelo amor do outro, pelo sentimento vivido, pela sua própria autonomia e liberdade, mas, acima de tudo, demandas (no plural) da felicidade própria. Única, singular e insubstituível.

RECEBIDO: $21 / 11 / 2020$ APROVADO: $31 / 05 / 2021$

\section{REFERÊNCIAS}

COELHO, Lauro Machado. A ópera na França. São Paulo: Perspectiva, 1999.

CASIMIRO, Cláudia. Tensões, tiranias e violência familiar: da invisibilidade à denúncia. In: MATTOSO, José (coord.). História da vida privada em Portugal: os nossos dias. Lisboa: Círculo de Leitores, 2011, p. 112-140.

MELO, Helena Pereira de. Os direitos das mulheres no Estado Novo: A Segunda Grande Guerra. Coimbra: Almedina, 2017.

MONGINHO, Julieta. A terceira mãe. Porto: Porto Editora, 2019.

. À tua espera. Lisboa: Dom Quixote, 2000 .

_ooob.

POLICARPO, Verónica. Sexualidades em construção, entre o privado e o público. In: MATTOSO, José (coord.). História da vida privada em Portugal: os nossos dias. Lisboa: Círculo de Leitores, 2011, p. 48-79.

SAMPAIO, Maria de Lourdes Morgado. Julieta Monginho: entre a luz e a sombra, entre os sons e os silêncios. Revista da Faculdade de Letras Línguas e Literaturas, II Série, vol. XXII, Porto, 2005, p. 549-579. 
VILA MAIOR, Dionísio. Julieta Monginho e o "vôo final das aves". In: PETROV, Petar (org.). O romance português pós-25 de Abril. O Grande Prémio de Romance e Novela da Associação Portuguesa de Escritores (2003-2014). Lisboa: CLEPUL, 2017, p. 53-60. Disponível em: https://repositorioaberto.uab.pt/bitstream/10400.2/8314/1/VILA\%20 MAIOR\%2c\%2oDion\%c3\%adsio_2017_Julieta\%2oMonjinho\%2c\%20 pp.53-6o.pdf Acesso em: 14 de novembro de 2020.

\section{MinicurRículo}

Jorge Vicente Valentim é Licenciado em Letras pela UFRJ, onde também concluiu o Bacharelado em Música (Piano), o Mestrado e o Doutorado em Letras (Literatura Portuguesa). Atualmente, é Professor Associado de Literaturas de Língua Portuguesa (Literatura Portuguesa e Literaturas Africanas de Língua Portuguesa) do Departamento de Letras e Professor Permanente do Programa de Pós-Graduação em Estudos de Literatura da UFSCar/SP. Finalista do Prémio Jabuti, em 2017, na categoria "Teoria e Crítica Literária", com a obra "Corpo no outro corpo": homoerotismo na narrativa portuguesa contemporânea (EDUFSCar, 2016). Vice-Presidente da ABRAPLIP, Gestões 2016-2017 e 2020-2021.

Ailton Pirouzi Júnior é Graduado em Letras pela UEL e encontra-se em fase de conclusão da Graduação em Ciências Sociais, pela Universidade Metropolitana de Santos. Professor de Português e Literaturas das redes pública e privada do Estado de São Paulo. Atualmente, é mestrando em Estudos de Literatura no PPGLit/UFSCar, onde desenvolve projeto de pesquisa sobre a ficção do escritor português Pedro Vieira, sob a orientação do Prof. Dr. Jorge Vicente Valentim. 